\title{
Ceramics and the Spanish Conquest
}




\title{
The Early Americas: History and Culture
}

\author{
General Editor \\ Alexander Geurds, Leiden University \\ Editorial Board \\ Willem Adelaar, Leiden University \\ Nikolai Grube, Bonn University \\ John Hoopes, University of Kansas \\ Maarten Jansen, Leiden University \\ Arthur Joyce, University of Colorado \\ Michael Smith, Arizona State University \\ Eric Taladoire, Sorbonne \\ Laura Van Broekhoven, National Museum of Ethnology, Leiden
}

VOLUME 2 


\title{
Ceramics and the Spanish Conquest
}

\author{
Response and Continuity of Indigenous Pottery \\ Technology in Central Mexico
}

By

Gilda Hernández Sánchez

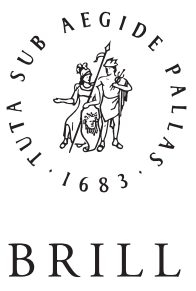

LEIDEN • BOSTON

2012 
The digital edition of this title is published in Open Access.

This book is printed on acid-free paper.

Library of Congress Cataloging-in-Publication Data

Hernández Sánchez, Gilda.

Ceramics and the Spanish conquest : response and continuity of indigenous pottery technology in central Mexico / by Gilda Hernández Sánchez.

p. cm. - (The early Americas: history and culture vol.2)

Includes bibliographical references.

ISBN 978-90-04-20440-9 (hardback : alk. paper)

1. Indian pottery-Mexico. 2. Indians of Mexico-Material culture. 3. Indians of MexicoAntiquities. 4. Pottery craft-Mexico-History. 5. Mexico-Antiquities. 6. MexicoHistory-Conquest, 1519-1540. 7. Mexico-History-Spanish colony, 1540-1810. I. Title.

F1219.3.P8H37 2012

972'.01-dc23

2011035865

ISSN $1875-3264$

ISBN 9789004204409

Copyright 2012 by Koninklijke Brill NV, Leiden, The Netherlands.

Koninklijke Brill NV incorporates the imprints Brill, Global Oriental, Hotei Publishing, IDC Publishers, Martinus Nijhoff Publishers and VSP.

All rights reserved. No part of this publication may be reproduced, translated, stored in a retrieval system, or transmitted in any form or by any means, electronic, mechanical, photocopying, recording or otherwise, without prior written permission from the publisher.

Authorization to photocopy items for internal or personal use is granted by Koninklijke Brill NV provided that the appropriate fees are paid directly to The Copyright Clearance Center, 222 Rosewood Drive, Suite 910, Danvers, MA 01923, USA.

Fees are subject to change. 
To my country,

which after everything continues looking with positive eyes into the future 


\section{CONTENTS}

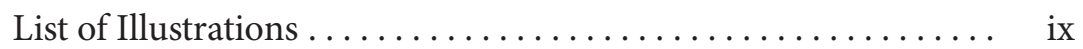

List of Maps and Table ................... xiii

Acknowledgments ....................... Xv

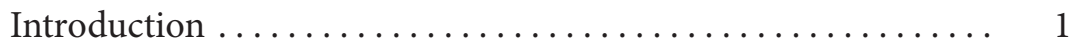

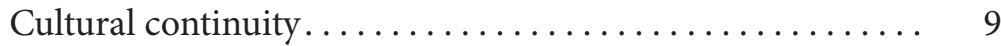

A note on some terms used ................ 13

Organization of this work ................ 15

I. Archaeology of Colonialism ... . . . . . . . . . . . . . . 19

Colonies, colonization and colonialism ............ 19

Post-colonial thinking .................. 21

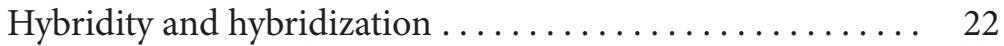

Archaeology of colonialism. . . . . . . . . . . .... 24

The archaeology of colonialism in Mesoamerica........ 25

II. The Study of Material Culture. . . . . . . . . . . . . . 29

The study of material culture ................ 29

Change in material culture ................ 31

A method to study change in material culture......... 33

Conservatism of potters................. 36

Change and continuity in pottery-making ......... 39

Summary ...................... 41

III. Ceramic-Making before the Conquest . . . . . . . . . 43

Sources to study late pre-colonial ceramics . . . . . . . . 47

Organization of ceramic production ............. 49

The impact of the Aztec empire on ceramic-making . . . . . 80

Ceramics as ritual objects and media of literacy ....... 83

Summary ......................... 89

IV. Ceramic-Making in Early Colonial Times ............ 91

Sources to study early colonial ceramics . . . . . . . . . 95

Organization of ceramic production . . . . . . . . . . 100

The impact of the Spanish ceramic technology . . . . . . . 140 
Ceramics as indices of cultural affiliation in early colonial central Mexico ............................. 145

Early colonial ceramics in central Mexico ............ 149

V. Ceramic-Making at Present .................... 153

Sources to study present-day ceramics . . . . . . . . . . . . 159

Organization of ceramic production ................. 164

The environmental impact of ceramic-making .......... 194 Impact of institutional programs to stimulate ceramicmaking............................... 197

Present-day ceramics in central Mexico . ........... 203

VI. Ceramics, Cultural Continuity and Social Change ........ 207 The development of ceramic-making during early colonial times............................... 211

The development of ceramic-making at present ........ 215 Ceramics and cultural continuity................ 217 The role of material culture in the process of colonization $\quad 220$ Reactions of Mesoamerican potters to the colonization.... 222 The prospects for ceramic-making. . . . . . . . . . . . 224

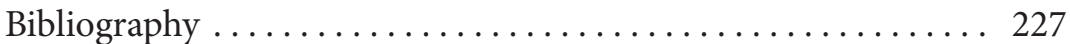

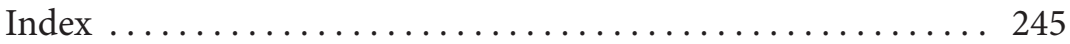




\section{LIST OF ILLUSTRATIONS}

1. Fragments of Late Aztec Black-on-Orange vessels from the valley of Mexico .................................. 60

2. Fragments of late pre-Hispanic Red Wares from the valley of Mexico ....................................

3. Fine polychrome vessel with pictographic decoration from a burial in Cholula (Suárez 1989) deposited at INAH Puebla (photo by Sergio Suárez) .................................

4. Patterns of decoration on Early and Late Aztec Black-on-Orange vessels from the valley of Mexico: (a) Early Aztec tripod bowl (based on Minc et al. 1994: Fig. 6.2a) (b) Early Aztec bowl (based on Minc et al. 1994: Fig. 6.3b) (c) Early Aztec bowl (based on Minc et al. 1994: Fig. 6.3d) (d) Early Aztec tripod plate (based on Minc et al. 1994: Fig. 6.4f) (e) Early Aztec bowl (based on Cervantes et al. 2007: Fig. 9) (f) Early Aztec plate (based on Cervantes et al. 2007: Fig. 14) (g) Early Aztec plate (based on Minc et al. 1994: Fig. 6.4k) (h) Early Aztec plate (based on Cervantes et al. 2007: Fig. 23) (i) Early Aztec bowl (based on Minc et al. 1994: Fig. 6.6h) (j) Early Aztec bowl (based on Minc et al. 1994: Fig. 6.5i) (k) Early Aztec tripod bowl (based on Minc et al. 1994: Fig. 6.5k) (1) Late Aztec tripod bowl (based on Cervantes and Fournier 1995: Fig. 2) (m) decoration pattern on Late Aztec plate (based on Cervantes and Fournier 1995: Fig. 8) (n) Late Aztec plate (based on Cervantes and Fournier 1995: Fig. 5) and (o) decoration pattern on Late Aztec bowl (based on Cervantes and Fournier 1995: Fig. 9) .....

5. Patterns of decoration on late pre-Hispanic Red Wares from the valley of Mexico: (a) Early Aztec Black-on-Red bowl (based on Cervantes et al. 2007: Fig. 15) (b, c) Late Aztec Black-on-Red bowls (based on Charlton et al. 1995: Fig. 1) (d, e, f) Late Aztec Black-on-Red bowls (based on Cervantes et al. 2007: Fig. 61) (g, h, i) Late Aztec Black-on-Red vessels (based on Charlton et al. 2007: Fig. 19) (j, k, l) Late Aztec White-and-Black-on-Red bowls (based on Cervantes et al. 2007: Fig. 62) (m) Late Aztec Whiteon-Red bowl (based on Cervantes et al. 2007: Fig. 39) (n, o) Late Aztec White-and-Black-on-Red bowls (based on Cervantes et al. 2007: Fig. 43) ..............................

6. Pictographic decoration on late pre-Hispanic fine polychrome vessels from Cholula: (a) goblet deposited at INAH-Puebla (b) censer deposited at Universidad de las Américas-Puebla (c) plate of fry- 
ing-pan censer deposited at INAH-Puebla (d) goblet deposited at Universidad de las Américas-Puebla.

7. Late pre-Hispanic vessel shapes in the valley of Mexico: $(a, b, c)$ ollas (d) basin with upright walls (e) basin with flaring walls (f) comal (g.h, i) censers $(\mathrm{j})$ pitcher $(\mathrm{k})$ basin with upright walls $(\mathrm{l}$, $\mathrm{m}$ ) hemispherical bowls (n) bowl with upright walls (o) hemispherical bowl (p) bowl with upright walls (q) bowl with flaring walls $(\mathrm{r})$ dish $(\mathrm{s})$ tripod bowl with flaring walls $(\mathrm{t})$ molcajete $(\mathrm{u})$ bowl with upright walls $(\mathrm{v}, \mathrm{w})$ miniatures $(\mathrm{x}, \mathrm{y})$ goblets $(\mathrm{z}, \mathrm{aa}, \mathrm{bb}$, cc) bowls with upright bowls (dd) bowl with composite silhouette (ee) goblet (ff, gg) bowls with upright walls (hh) plate. Not

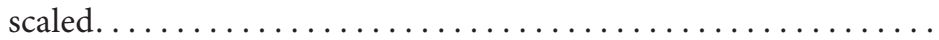

8. Shapes of late pre-Hispanic polychrome vessels with pictographic decoration from Cholula: (a, b, c) bi-conical vases (d) vase (e) goblet (f) tripod bowl with flaring walls (g) bowl with flaring walls (h) hemispherical bowl (i) plate (j, k) censers (l) composite silhouette basin $(\mathrm{m})$ crater $(\mathrm{n})$ bottle

9. Fine polychrome vessels from Cholula with pictographic decoration representing the "complex of the solar band": (a) hemispherical bowl deposited at the Universidad de las Américas-Puebla (b) plate deposited at INAH-Puebla (c) crater deposited at INAH-

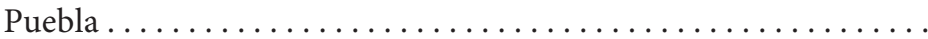

10. Fine polychrome vessels from Cholula with pictographic complexes with religious and ritual connotations: (a) vase referring to the cult of the ancestors deposited at INAH-Tlaxcala (b) vase referring to propitiation of agricultural fertility deposited at INAH-Tlaxcala (c) bi-conical vase referring to pulque and fertility deposited at Universidad de las Américas-Puebla (d) goblet referring to actions around warfare deposited at Universidad de las Américas-Puebla (e) censer referring to the invocation of Quetzalcoatl deposited at INAH-Puebla (f) plate referring to the invocation of powerful

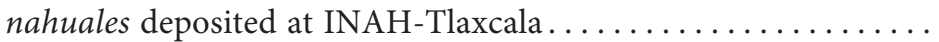

11. Fragments of ollas from the valley of Mexico with juncture marks showing that they were made using two or three horizontal molds as in pre-Hispanic times $\ldots \ldots \ldots \ldots \ldots \ldots \ldots \ldots \ldots \ldots \ldots \ldots$

12. Fragments of vessels made by wheel with compression rings on the interior of the walls .

13. Fragments of early colonial Red Wares from the valley of

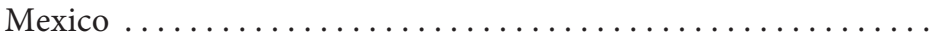

14. Fragments of early colonial Black-on-Orange wares from the val-

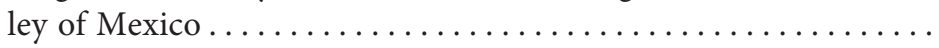


15. Early colonial fine polychrome vessel with pictographic decoration from Cholula.

16. Fragments of early colonial molcajetes with lead glaze from the valley of Mexico

17. Patterns of decoration on early colonial Black-on-Orange wares from the valley of Mexico: (a, b, c, d) molcajetes and tripod bowls (based on Charlton et al. 2007: Fig. 12) (e, f, g, k) molcajetes and tripod bowls (based on Charlton et al. 2007: Fig13) and (h, i, j, l) molcajetes (based on Charlton et al. 2007: Fig. 14)

18. Patterns of decoration on early colonial Red Wares from the valley of Mexico: $(a, b)$ bowls with flared walls (based on Charlton et al. 1995: Fig. 6) (c) bowl with upright walls (based on Charlton et al. 1995: Fig. 5) (d) plate with interior decoration (based on Charlton et al. 1995: Fig. 8).

19. Patterns of decoration on early colonial lead glazed wares from the valley of Mexico

20. Patterns of decoration on early colonial Majolica wares from the valley of Mexico (based on Lister and Lister 1987: Fig. 85)....

21. Shapes of early colonial serving vessels from the valley of Mexico: (a, b) ollas (based on Charlton et al. 2007: Fig. 68) (c) hemispherical bowl (based on Charlton et al. 2007: Fig. 69) (d) tripod molcajete (based on Charlton et al. 2007: Fig. 66) (e, f) tripod bowls (based on Charlton et al. 2007: Fig. 15) (g) plate (h, i) tripod bowls (based on Charlton et al. 2007: Fig. 23 Rodríguez Alegría 2002: Fig. A.1) (j, k, l, m) bowls (n) plate (o, p, q) goblets (based on Charlton et al. 2007: Fig. 26; Rodríguez Alegría 2002: Fig. A.1).

22. Vessel shapes depicted in the Códice de los Alfareros de Cuauhtitlan with the names given in the document: (a) molcaxete para cacaos $(b, c)$ alcarrazas (d) jarro (e, f) goblets without name in the document (g) plate with incisions on the bottom without name in the document (h) tinaja (i) pitcher without name in the document (j) alcarraza (k) bottle with lid without name in the document (l) alcarraza (m) jarro pichel (n) alcarraza (o, p, q) jarros (r) sugar bowl without name in the document (s) jarro como caracol (t) jarro la hechura como negrito $(\mathrm{u})$ jarro (kidney-shape bowl with an appendage on the rim modelled as a Spanish man and two handles) (v) jarro (kidney-shape bowl with a plate -or a pedestal base- and two handles on the rim viewed from the top).

23. Vessel shapes made with the potter's wheel in the valley of Mexico: (a, b) bacín (c) bacinilla (d, e) lebrillo (f) cántaro (g) tinaja (h) orza (i) jarra (j) pitchel (k) hidroceramo (botija) (l) albarelo 
$(\mathrm{m}, \mathrm{n})$ plato $(\mathrm{o})$ taza $(\mathrm{p})$ pocillo $(\mathrm{q})$ escudilla (based on Deagan 1987: Fig. 4.1)

24. Process of clay preparation in Amozoc.

25. Process of clay preparation in Huasca (photo by Hermann Stützle)

26. Process of vessel forming by molding................................ 171

27. Ollas made with two vertical halve-molds in San Juanico .......... 171

28. Process of vessel forming in Metepec (photo by Hermann Stützle)

29. Process of vessel forming in San Miguel Tenextatiloyan

30. Process of vessel forming in Amozoc (photo by Hermann Stützle).

31. Small factory for fine paste ceramics in Santa Cruz Texcoco ......

32. Lead glazed wares from central Mexico in the market of Sonora in Mexico City (photo by Hermann Stützle)

33. Application of greta on vessel before the second firing in Amozoc (photo by Hermann Stützle)....

34. Process of surface finishing of vessels in Los Reyes Metzontla . . 179

35. Process of firing in Metepec (photo by Hermann Stützle) ......... 181

36. Decoration of ollas in San Miguel Tenextatiloyan.

37. Methods and styles of decoration in: (a) Amozoc (b) Metepec (c) Santa Cruz Texcoco (d) Santa María Canchesdá (e) Huasca and (f) Santiago Coachochitlan

38. Shapes of vessels made in Santa Cruz Texcoco ........................ 189

39. Cazuelas for mole in a workshop in Amozoc............................ 191

40. Ollas for piñatas in San Juanico ........................................ 191

41. Artesanías manufactured in Los Reyes Metzontla.................... 202 


\section{LIST OF MAPS AND TABLE}

\section{MAPS}

1. Map from central Mexico showing the places mentioned in the text

2. Map from the valley of Mexico showing the places mentioned in the

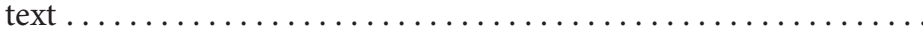

\section{TABLE}

1. Indigenous vessels' nomenclature in Nahuatl, English and Spanish registered in the tenth book of the Florentine Codex (Sahagún 1961, X:83)............................ 137 


\section{ACKNOWLEDGMENTS}

This study concentrates the results of the research project "Ceramics and Social Change. The Impact of the Spanish Conquest on Middle America's Material Culture" carried out from 2006 to 2010, under the generous support of a VENI grant from the Innovational Research Incentives Scheme of the Netherlands Foundation for Scientific Research (NWO) and the Faculty of Archaeology of Leiden University. I thank Maarten Jansen whose erudition and kindness were constantly present in this project. My special gratitude is to all the potters, who kindly gave me their time and knowledge and permitted me to observe their work and make pictures, in particular: in Amozoc: José Orlando Ramírez Torres, Juan Robles, Juan Antonio and Alejandro Sánchez and family, Dolores Zepeda and Clemente Sánchez Romero and family; in Santa María Canchesdá: José Luís Gonzáles, Zelia de la Cruz Hernández y Benjamín Martínez de la Cruz, Orlando Martínez Bernal, Abundio Ratana Martínez; in Santiago Coachochitlan: Manuel de Jesús Bernal, Fidel Isaac Durán and wife, Jorge González, Cristina Hernández, Norberto Martínez; in San Juanico: Juan Barrera and family, Juan Flores Flores, León Flores Flores; in San Miguel Tenextatiloyan: family Aguirre Mendez, Pablo Bonilla Ortega and family, Alejandra Castillo and Maribel García, Celeriano Hernández, Elodia Lucas Hernández, Emilia Juárez Hernández, family Luna Vallejo, Guadalupe Payno Allende, Atanasia Ramos and family, Manuel Zaragoza Martínez; in Metepec: Miguel Ángel Camacho García, Javier Carrillo, Teobaldo Hernández, Manuel León Montes de Oca, Patricio Ramírez, Family Torres Carrillo; in Santa Cruz Texcoco: José Trinidad Alonso Bustamante, Roberto Espejel Huesques, Juan García, Humberto Ramírez, Jocundo Rodríguez; in Huasca: Fausto Cortés and wife, José Alberto Cortés and wife, Juan Rafael Franco; in Cuauhtitlan: Delfino Cano, Fernando Payares and wife, Jesús and Carmelo Payares; in San Juan Coajomulco: María Isabel González; in Tepexoyuca: Gabriel Díaz Sánchez; in Los Reyes Metzontla Isaí Vera Carrillo; in Santo Domingo Tonaltepec: Tomasa Bautista Ramírez, Concepción Cruz, Dorotea Miguel González, Juana Montero, Nieves Nabora Cruz.

In addition, Fernando Getino and Israel Fuentes kindly showed me ceramics from their excavation at Las Palomas in the north of the 
valley of Mexico. Jorge Alberto Quiróz Moreno gave me access to the ceramic samples of the Departamento de Colecciones Arqueológicas Comparativas of Instituto Nacional de Antropología e Historia (INAH) in Mexico. Thanks to Jeffrey Parsons for allowing consulting ceramic collections of the Basin of Mexico Archaeological Project conserved at the University of Chapingo. Thanks are due also to the late William Sanders and George Cowgill, who gave me permission to consult the collections of the Teotihuacan Valley Project conserved in the laboratory of Arizona State University at San Juan Teotihuacan. Sergio Suárez Cruz from the INAH Puebla gave me permission to consult a collection of archeological colonial ceramics from Cholula, and let me consult a report on petrographic analysis of Cholula ceramics. Enrique Rodríguez Alegría kindly sent me a copy of his dissertation about ceramic production and consumption in colonial Mexico, Martha Adriana Sáenz gave me a copy of her BA thesis on the study of late colonial ceramics from the parish of San Andrés in Cholula, and Michael Smith sent a copy of his INAH reports on the ceramics of Yautepec, Morelos. The Museo Arqueológico de Sevilla and the Museo de Historia de Valencia gave me access to their ceramic collections of sixteenth century Spain. Rosanna Woensdregt made a new transcription of the alphabetic text of the Códice de los Alfareros de Cuauhtitlan. Abraham van As, Lou Jacobs and four students of the Faculty of Archaeology of Leiden University (Meliam Vigano Gaspar, Paul van Akkeren, Andreia Kroezen and Michiel Esveld) participated in and enriched a short fieldwork season. Many thanks to Alex Geurds who kindly checked and improved the last version of the manuscript. Also I want to thank Hermann Stützle who made many of the pictures here presented (his authorship will be indicated in the captions). Finally, many ideas of friends and colleagues enriched this manuscript, especially Hermann Stützle, Araceli Rojas Martínez Gracida, Aurora Pérez Jiménez, Carolina Aretz, Rosanna Woensdregt, Teresa Salomón and Yunuen Rhi. 